\title{
THE EFFECT(S) OF DIFFERENT WEED CONTROL METHODS ON WEED INFESTATION, GROWTH AND YIELD OF SOYBEANS (GLYCINE MAX (L) MERRIL) IN THE SOUTHERN GUINEA SAVANNA OF NIGERIA
}

\author{
E.O. Imoloame \\ Kwara State University, Malete, P.M.B. 1530, Ilorin
}

\begin{abstract}
A field experiment was conducted during the 2012 and 2013 rainy season at the Kwara State University Teaching and Research Farm located in Malete. The aim was to determine the effect(s) of different weed control methods on Weed infestation, growth and yield of soybeans (variety TGX $1448-2 E)$. The experiment consisted of 8 treatments, namely, the application of metolachor at 1.5, $2.0 \mathrm{nd} 2.5 \mathrm{~kg}$ a.i./ ha, pendimethalin at 1.5, 2.0 and $2.5 \mathrm{~kg}$ a.i./ha, a tank mixture of metolachlor + diuron at $1.5+0.5,2.0+1.0$ and $2.5+1.5 \mathrm{~kg}$ a.i./ha, pendimethalin + diuron at $1.5+0.5,2.0+1.0$ and $2.5+1.5 \mathrm{~kg}$ a.i./ha, metolachor at $2.0 \mathrm{~kg}$ a.i. /ha plus I supplementary hoe weeding (SHW) at 6 WAS, pendimethalin at $2.0 \mathrm{~kg}$ a.i. /ha plus supplimentary hoe weeding (SHW) at 6WAS, metolachlor + diuron at $1.0+0.5 \mathrm{~kg}$ a.i. /ha plus ISHW, pendimethalin + diuron at $1.5+0.5$ plus ISHW at 6 weeks after sowing (WAS), weeding at 3 and 6 WAS and a weedy check. Results showed that all the herbicide treatments significantly reduced weed infestation compared to the weedy check. However, metolachlor + diuron integrated with ISHW was more effective than the application of only herbicides in the control of weeds throughout the crop life. This weed control method also resulted in significantly better growth and higher yield. Therefore for better growth and higher yields, metolachlor + diuron integrated with ISHW at 6WAS is recommended to formers in the Southern Guinea Savanna of Nigeria.
\end{abstract}

Key word: methods of weed control, soybean, southern Guinea savanna, Nigeria

\section{INTRODUCTION}

Soybeans (Glycine max (L.) Merril) account for more than $50 \%$ of the world oil seed output (Joshi, 2001). In tropical Africa, important countries known for soybean production are Zambia, Nigeria, Zimbabwe, Zaria, Rwanda, Uganda and Ethiopia. The average yield of soybean in Nigeria is $1,000 \mathrm{~kg} \mathrm{ha}^{-1}$, while the world average yield is about $1,800 \mathrm{~kg} \mathrm{ha}^{-1}$. However, with proper management, it is possible to obtain $2,500 \mathrm{~kg} \mathrm{ha}^{-1}$ (Onwueme and Sinha, 1991). Soybean is an important grain legume and source of vegetable protein (Anon, 1994). It is popular as golden been and has become the miracle crop of the $21^{\text {st }}$ century. It serves the dual purpose of being grown both as an oil crop and pulse crop as well (Thakareetal. 2006). The crop has an average protein content of $40 \%$ and is more protein - rich than any of the common vegetable or animal food sources found in Nigeria (Dugjeet al., 2009). In addition to its use as a source of protein and fodder, soybean can improve soil fertility by contributing to soil nitrogen through 
nitrogen fixation (Kureh et al., 2005). It can be used for soy-milk and vegetable oil, as soybean seed contains about $20 \%$ oil on a dry matter basis and this is $85 \%$ unsaturated and cholesterol free (Dugje et al.,2009).

Poor soybean yield in farmers' plots is attributable to weed-crop competition and low soil fertility (Sodangi et al., 2011)Jannink (2000) reported that weed interference is the main factor that causes soybean grain yield reduction. Sodangi et al. (2006) reported a soybean grain yield loss of up to $99 \%$ due to weed infestation in the Sudan Savanna zone of Nigeria. This is because in the early growth stages, soybean is a poor competitor with fast growing weeds and if such weeds are not controlled, they may out grow the crop (Sodangiet al., 2007). Also, Daugovishet al. (2003) reported that up to $80 \%$ yield loss of soybean may occur as a result of weed competition in many parts of the world

Traditional manual weeding is the most popular method of weed control in Nigeria. This is, however, time consuming, labour - intensive, strenuous and generally expensive (Joshua and Gworgwor, 2000; Adigun and Lagoke, 2003). It is estimated that about $40-60 \%$ of production cost is spent on manual weeding (Remison, 1979). In addition to high cost, labour availability is uncertain, thus making timeliness of weeding difficult to attain, leading to greater yield loss (Adigun and Lagoke, 2003).

Herbicide use is one of the developments which was introduced later to control weeds in crop production. It is more adapted to large scale production and labour saving (Anon, 1994). Other factors that have made chemical weed control more popular than manual weeding include reduction of drudgery in chemical weed control, it protects crops from the adverse effects of early weed competition which can avert economic losses in soybean that needs early weed control in the first four weeks as this is the critical period of weed competition in soybean (Gesimba and Langat, 2005). It is a faster weed control method (Akobundu, 1987 ). Furthermore, the use of herbicides is more profitable than hoe-weeding in the production of most crops in Nigeria (Shrock and Monaco, 1980; Okereke, 1983; Sinha and Lagoke, 1984; Ogungbile and Lagoke, 1986; Adigun et al., 1993 and Imoloame et al., 2010). Imoloame ( 2009), reported that in 2006 and 2007 diuron at $1.0 \mathrm{~kg}$ a.i./ha and metolachlor at $1.5 \mathrm{~kg}$ a.i./ha gave higher profits of N39,240.74 and N83,115.74 respectively than two hoe weedings at 3 and 6 WAS with profits of N22,407,41 and N72,365.74 respectively in the two years being studied. Their judicious use has been reported to reduce the cost of weed control, increased crop yields by reducing weed competition and consequently increased profitability. (Ogungbile and Sinha, 1982). A survey carried out by Ikuenobe et al. (2005) and Imoloame (2013), showed that majority of farmers using herbicides indicated savings in labour and cost of production, better weed control and higher crop yields.

The Kwara State government is determined to modernize agriculture and make farming more attractive through the reduction of drudgery. Therefore, this trial was designed to evaluate 
different methods of weed control in order to determine the one that will be most effective in weed control and result in higher soybean grain yield.

\section{MATERIALS AND METHODS}

A field experiment was conducted during the 2012 and 2013 rainy seasons at the Teaching and Research Farm of Kwara State University, Malete, (lat. 080, 71'N; long.04044'E) at 360m above sea level. The experiment consisted of 18 treatments, namely, the application of metolachlor at $1.5,2.0$ and $2.5 \mathrm{~kg}$ a.i./ha, pendimethalin at $1.5,2.0$ and $2.5 \mathrm{~kg}$ a.i./ha, a tank mixture of metolachlor + diuron at $1.5+0.5,2.0+1.0$ and $2.5+1.5 \mathrm{~kg}$ a.i.//ha, pendimethalin + diuron at 1.5 $+0.5,2.0+1.0$ and $2.5+1.5 \mathrm{~kg}$ a.i./ha metolachlor at $2.0 \mathrm{~kg}$ a.i./ha plus I supplementary hoe weeding (SHW) at 6 weeks after sowing (WAS),pendimethalin at $2.0 \mathrm{~kg}$ a.i./ha plus $1 \mathrm{SHW}$ at 6 WAS, metolachlor+diuron at $1.0+0.5$ plus ISHW, pendimethalin+diuron at $1.5+0.5$ plus ISHW at 6 WAS, hoe weeding at 3 and 6WAS and a weedy check. These treatments were laid out in a Randomized Complete Block Design (RCBD) and replicated three times. The variety of soybean that was used was TGX 1448 - 2E which was sown on $2^{\text {nd }}$ of July 2012 and 28 June, 2013 and harvested on the $15^{\text {th }}$ and $7^{\text {th }}$ of November, respectively. The crop was spaced at $40 \mathrm{~cm} \times 10 \mathrm{~cm}$ to give a plant population of $500,000 /$ ha. Herbicides were applied a day after planting with a CP3 knapsack sprayer which was calibrated to deliver $250 \mathrm{~L} /$ ha spray volume. Fertilizer was applied at the rate of $20 \mathrm{~kg} \mathrm{~N}, 20 \mathrm{~kg} \mathrm{P}$ and $10 \mathrm{~kg} \mathrm{k} \mathrm{k}_{2} \mathrm{O}$. These were provided with a compound fertilizer 15:15:15. The gross plot was $9 \mathrm{~m}^{2}$. The outer rows of the gross plot was discarded while only the 5 inner rows were harvested and weighed. The parameters measured were plant height, weed dry matter, weed cover scores, crop vigour, phytotoxicity, 100 - seed weight and soybean grain yield. The crop vigour was assessed visually at 6 and 9 WAS, using a scale of 1 to 9 , where 1 is complete dead plants and 9 is the most vigorous plants. Plant height was determined at 6 WAS and at harvest by selecting 5 plants randomly from a plot and then measured their heights from the soil level to the tip of the apical bud with a graduated meter ruler. The mean of the plant heights was recorded as plant height per plot. The weed dry matter was determined at 6 WAS and at harvest by harvesting weed biomass from 3 randomly located $1 \mathrm{~m}^{2}$ quadrat in each experimental plot. The weeds were later oven-dried, weighed and the average weight was recorded. The weed cover score was determined 6 WAS and at harvest using a scale of 1 to 9 , where 1 is complete absence of weeds and 9 is complete coverage of the plot by weeds. The 100 -seed weight was determined by counting 100 seeds from the bulk of seeds harvested from each plot. This was weighed and converted to kilograms per hectare. The grain yield was determined after harvest. Seeds harvested per plot were weighed and the result converted to kilograms per hectare to give the grain yield of soybeans per hectare. The phytotoxic rating was taken at 2, 4 and 8 WAS using a scale of 1 to 9 , where 1 is no crop injury and 9 is complete crop 
kill. Data collected were subjected to analysis of variance and means were separated using Duncan's Multiple Range Test at $5 \%$ level of probability.

\section{RESULTS AND DISCUSSION}

Weeds observed on the experimental farm included, Celosia leptostachya Benth, Hyptis lanceolata Poir, Mariscus alternifolius vahL (=M. unbellatusVahl), Hyptis suaveolens Poit and Leucas martinicensis which occurred at high levels of infestation, while Daniellia oliverl, commelina benghalensis, Cyperus esculentus, Cyperus roturdus, Brachiaria Lata, Chloris pilosa, Dactyloctenium aegytium, Digitaria horizontalis, Pennisetum Pedicellatum and Rottboelia conchinchinensis occurred at lower level of infestation.

Table 1 shows the effect of different methods of weed control on weed dry matter at 6WAS and harvest. It shows that different methods of weed control significantly affected weed dry matter in both years and their mean. Weeding twice at 3 and 6 WAS significantly reduced weed dry matter at 6 WAS compared to the other treatments in both years and the mean except metolachlor at $1.5 \mathrm{~kg}$ a.i./ha, pendimethalin at 2.0 and $2.5 \mathrm{~kg}$ a.i./ha, a tank mixture of metolachlor + diuron at $2.0+1.0$ and $2.5+1.5 \mathrm{~kg}$ a.i./ha, a tank mixture of pendimethalin + diuron at $2.5+1.5 \mathrm{~kg}$ a.i./ha, metolachlor at $2.0 \mathrm{Kg}$ a.i. plus I SHW, metolachlor + duiron and pendimethalin + diuron at 1.5 $+0.5 \mathrm{~kg}$ a.i./ha integrated with I SHW. Weedy check supported significantly higher weed infestation. However at harvest, metolachlor + diuron and pendimethalin + diuron at $1.5+0.5 \mathrm{~kg}$ a.i./ha integrated with $1 \mathrm{SHW}$ at 6 WAS, two hoe weedings, metolachlor and pendimethalin at $2.0 \mathrm{~kg}$ a.i./ha integrated with ISHW sustained their effectiveness in the control of weeds till harvest. Metolachlor + diuron at $1.5+0.5$ integrated with I SHW at 6 WAS and pendimethalin at $2.0 \mathrm{~kg}$ a.i./ha plus $1 \mathrm{SHW}$ supported significantly lower weed dry mater in both years and the combined than the other weed control treatment except hoe weeding at 3 and 6WAS pendimethalin at $2.0 \mathrm{~kg}$ a.i./ha in 2013 and metolachlor at $2.0 \mathrm{~kg}$ a.i./ha plus ISHW in 2012 . The ability of metolachlor + diuron at $1.5+0.5 \mathrm{~kg}$ a.i./ha plus $1 \mathrm{SHW}$, metolachlor and pendimethalin at $2.0 \mathrm{~kg}$ a.i./ha plus $1 \mathrm{SHW}$ to give season-long weed control, clearly underscores the importance of integrated weed management in enhancing weed control compared with the use of single weed control method. (Table 1). Also using only herbicides at all the doses tested were only effective in weed control up to 6 WAS. However they became ineffective with time.

The effect of different methods of weed control on weed cover scores at 6 WAS and at harvest is presented in Table 2. Different methods of weed control significantly affected weed cover scores. At 6 WAS in the mean, metolachlor at $2.0 \mathrm{~kg}$ a.i.lha supported significantly lower weed cover score than the other treatments, except pendimethalin at $2.0 \mathrm{~kg}$ a.i./ha plus I SHW, two hoe weedings, pendimethalin at $1.5+0.5 \mathrm{~kg}$ a.i./ha plus I SHW, metolachlor + diuron at $1.5+0.5$ and $2.5+1.5 \mathrm{~kg}$ a.i./ha and pendimethalin + diuron at $2.5+1.5 \mathrm{~kg}$ a.i./ha. However at harvest 
herbicides alone poorly controlled weeds, while two hoe weeding resulted in comparable significantly lower weed cover with metolachlor + duiron and pendimethaline + duiron at $1.5+0.5$ $\mathrm{kg}$ a.i./ha integrated with I SHW, and metolachlor or pendimethalin integrated with ISHW. Other herbicide treatments along with weedy check resulted in significantly higher weed cover scores in both years and their means. This result corroborates the findings of Peer (2013) that herbicide proved effective at higher rates when applied alone, however when combined with one hoe weeding, they were more effective, and that the initial achievement of limiting weed growth by the herbicides is maintained as hand weeding eliminates the fresh flush of weeds that may regenerate due to loss of persistence of herbicides applied alone. The integrated weed control method ensured early canopy closure which further suppressed late emerging weeds. This is in line with the report of (Gebharat and Minor, 1983; Murphy and Gossett, 1981; Mlckelson and Renner 1997; Yelverlon and Coble, 1991) that if weeds are controlled within the first five weeks after sowing, the canopy of narrow-sown soybean can suppress late emerging weeds. Table 3. presents the effect of different methods of weed control on phytotoxicity of soybean at 2, 4 and 8 WAS. In 2013 at 2 WAS, it was only pendimethalin at $2.0 \mathrm{~kg}$ a.i./ha and a tank mixture of pendimethalin + diuron at higher dose that were phytotoxic to soybean, however at time progressed to 4 WAS and 8 WAS this effect was neutralized. In the mean at 2 WAS, all the herbicide rates did not have any phytotoxic effect on soybean indicating that all the herbicides used were safe to be used for weed control in soybean (Table 3).

Table 4 presents the effect of different methods of weed control on soybean plant height at 6 WAS and at harvest. It shows that at 6 WAS, while different methods of weed control had no significant effect on soybean plant height in 2012, they affected soyabean plant height significantly in 2013 and the mean.

In both 2013 and the mean, metolachlor + diuron at $1.5+0.5 \mathrm{~kg}$ a.i./ha plus ISHW supported comparable significantly taller soybeans plants with other herbicides treatments and two hoeweedings except pendimethalin at 2.0 and 2.5 in 2013 and the mean respectively, pendimethalin + diuron at $2.0+1.0$ and pendimethalin + diuron at $1.5+0.5 \mathrm{~kg}$ a.i./ha plus supplementary hoe weeding in the mean and weedy check which supported significantly shorter soybean plants. However at harvest, all the weed control treatment produced significantly taller plants except pendimethalin at $2.0 \mathrm{~kg}$ a.i./ha, pendimethaline + diuron at $2.5+1.5 \mathrm{~kg}$ a.i./ha in 2013 and metolachlor and pendimethalin at $2.0 \mathrm{~kg}$ a.i./ha plus I SHW in the mean. Weedy check gave significantly shortest soybean plants. Plots treated with metolachlor + diuron at $1.5+0.5 \mathrm{~kg}$ a.i./ha and other weed control treatments supported significantly taller soybean plants than the weedy check because of their ability to effectively control weeds which allowed the soyabean plants to utilize more nutrient, moisture and sunlight for better performance. The shortest soyabean plants were produced by the weedy check as a result of the greater intensity of weed competition with 
crop for growth resources which led to poor performance of the crop. The shorter soybean plants observed under pendimentalin at $2.0 \mathrm{~kg}$ a.i./ha in 2013 and could be due to the slight phytotoxicity of the herbicides at the early stage of crop growth which disappeared as the plant grew older.

Table 5, shows the effect of different methods of weed control on soybean crop vigour. It shows that different methods of weed control affect soybean crop vigour at 6WAS and at harvest in 2013 and the mean. A tank mixture of metolachlor + dluron at $1.5+0.5 \mathrm{~kg}$ a.i./ha plus ISHW produced significantly vigorous crops which were comparable with other weed control treatments except pendimethalin at $2.0 \mathrm{~kg}$ a.i./ha in 2013 and pendimethalin + diuron at $2.5+1.5 \mathrm{~kg}$ a.i./ha and weedy check in 2013 and the mean which gave significantly weaker crops. At harvest, similar observation was obtained with a tank mixture of matolachlor + diuron at $1.5+0.5 \mathrm{~kg}$ a.i./ha plus ISHW producing significantly most vigorous crops in 2013 and the mean which was comparable to melolachlor at $2.0 \mathrm{~kg}$ a.i./ha, metolachlor + diuron at $1.5+0.5$ and $2.0+1.0 \mathrm{~kg}$ a.i./ha, pendimethalin + diuron at $1.5+0.5$ and $2.0+1.0 \mathrm{kga}$.i.lha, and two hoe weedings. The other weed control treatments and the weedy check resulted in significantly weaker plants. Metolachlor + diuron at $1.5+0.5 \mathrm{~kg}$ a.i./ha plus ISHW consistently produced significantly most vigorous crops as a result of its greater ability of this weed control method to control weeds more effectively than other control methods. This made more growth resources to be available for use by the crops under this treatment resulting in a better performance.

The weedy check consistently supported significantly weaker crops at 6WAS and harvest than the other weed control methods due to the greater weed competition with soybean crop which significantly reduced the amount of assimilates, nutrients, moisture and solar radiation utilized by the crop leading to poor performance.

Table 6 , presents the effect of different methods of weed control on 100-seed weight and soybean grain yield. The effect of different methods of weed control on 100-seed weight was not significant in 2012 while it was significant in 2013 and their mean. In 2013 and the combined, tank mixture of metolachlor + diuron at $1.5+0.5$ plus ISHW gave significantly heaviest soybean seeds which were comparable to metolachlor at $2.5 \mathrm{~kg}$ a.i./ha, pendimethalin at $1.5 \mathrm{~kg}$ a.i./ha pendimethalin + diuron at $1.5+0.5$ and $2.0+1.0 \mathrm{~kg}$ a.i./ha, pendimethalin at $2.0 \mathrm{~kg}$ a.i./ha plus I SHW, pendimethalin + diuron at $0.5+1.0 \mathrm{~kg}$ a.i./ha plus ISHW and two hoe weedings but significantly heavier than the rest of the weed control methods and weedy check. This further reveals the effectiveness of the above weed control methodsto significantly reduce weed cover thereby minimizing weed competition with the soyabean crop leading to uptake of more nutrients, moisture and sunlight and assimilate for the production of heavier seeds.

Similarly, different methods of weed control affect soyabean grain yield significantly only in both years and their mean. In 2012, all the weed control methods resulted in comparable significant 
higher grain yield than the weedy check. However in 2013, a tank mixture of metolachlor + diuron at $1.5+0.5 \mathrm{~kg}$ a.i./ha integrated with $1 \mathrm{SHW}$ produced significant higher grain yield than all the other weed control methods, except two hoe weedings at 3 and 6 WAS. Similar trend was observed in the mean with a tank mixture of metolachlor + diuron at $1.5+0.5 \mathrm{~kg}$ a.i./ha producing significant higher yield which was comparable with other weed control methods except metolachlor at 1.5 and $2.0 \mathrm{~kg}$ a.i./ha, pendimethalin at $1.5 \mathrm{~kg}$ a.i.//ha, metolachlor + duiron at 1.5 $+0.5 \mathrm{~kg}$ a.i./ha and the weedy check which produced significantly lower soybean grain yields. Generally, 2012 recorded higher grain yields across treatments than 2013. In 2012, all the weed control methods produced significantly higher soybean grain yield than the weedy check because the weed control methods significantly reduced weed infestation compared to the weedy check which allowed crops to utilize more growth factors for better growth. However, in the weedy check weed competition for growth resources with the soyabean crop was more intense, resulting in yield losses between $76.80 \%$ in 2012 and $89.3 \%$ in 2013 . The higher percentage of losses and lower grain yields recorded in 2013 compared to 2012, could be due to the prolonged period of drought that was experienced in 2013 which limited the amount of moisture, nutrients and assimilate that were taken up by the crop. This situation was worsened by the greater weed cover that was observed in the plots probably due to the reduction of the potency of the herbicides as a result of the drought condition.

Metolachlor + diuron at $1.5+0.5 \mathrm{~kg}$ a.i. /ha and weeding at 3 and 6WAS proved to be more effective than the other weed control methods as a result of their greater ability to continuously reduce weed infestation at the critical period of weed interference of soybean, thereby making more growth resources available to soybean for utilization. This led to significantly more vigorous crops, taller plants, heavier seed weight and higher grain yield. This result is similar to the findings of Peer et al. (2013) that hand weeding twice and both fluchoralin and pendimethalin integrated with hand weeding recorded far superior yields of soybean seed. Also, a number of researchers like Veeramaniet al. (2001) held similar views and reported more pods with integrated use of herbicides with hand weeding. Uncontrolled weeds resulted in $89.3 \%$ and $76.8 \%$ soyabean losses in 2012 and 2013 respectively. This lis similar to the findings of Sodangiet al. (2006) that soybean grain yield loss of up to $99 \%$ was due to weed infestation in the Sudan Savanna Zone of Nigeria.

\section{CONCLUSION}

In conclusion, this study has proved that application of a tank mixture of metolaclor + diuron at $1.5+0.5 \mathrm{~kg}$ a.i./ha integrated with $1 \mathrm{SHW}$ is not only effective in providing season-long control of weeds, but has promoted better growth and higher yield of soybeans. Therefore, this method of weed control is recommended to farmers in the southern Guinea savanna zone of Nigeria. 


\section{REFERENCES}

Adigun J.A., and Lagoke S.T.O. (2003). Weed control in transplanted rain and irrigated tomatoes in the Nigerian savanna. Nigerian Journal of Weed Science. 16: 23 - 29.

Adigun J.A., Lagoke S.T.O., Kumara V and Erinle I.D., (1993). Weed management studies in transplanted tomato in the Nigeria savanna. Samaru J. Agric. Res. 10:29-39.

Anonymous (1994). Soybean Production and Utilization in Nigeria. Extension Bulletin No.68. NAERLS, Federal Ministry of Agriculture and Natural Resources. ABU, Zaria.

Anonymous (1994). Weed control recommendation for Nigeria. Series 3, Federal Department of Agriculture, Federal Ministry of Agriculture, Nigeria. p1.

Daugovish O., Thill D.C., Shaft B. (2003). Modeling competition between wild oat (Avenafatua $L$ ) and yellow mustard or Canona. Weed Science 51:102 - 109.

Dugje I.Y., Omoigui L.O., Ekeleme F., Bandyopadhyay R., Kumar Lava P., and Kumara A.Y., (2009). Farmers' Guide to Soyabean Production in Northern Nigeria. International Institute of Tropical Agriculture, Ibadan, Nigeria. 21pp.

Gebhardt M.R. and Minor H.C. (1983). Soybean production systems for clay pan soils. Agronomy Journal 75: $532-573$

Gesimba R.M., Langart M.C. (2005). A review on weeds and weed control in oil crops with special reference to soybeans ( Glycine max L.) in Kenya. Agriculura Tropica et Subtropica 38 (2): 56-62

Ikuenobe C.E., Fadayomi I.O., Adeosun J.O, Gworgwor N.A., Melifonwu A.A., Ayeni A.O., (2005). State of adoption of improved weed control technologies by farmers in three agro-ecological zones of Nigeria.

Nig. J. Weed Science. 18:1 - 19.

Imoloame E.O. (2009). Effects of pre- and post-emergence herbicides on weed infestation and productivity of sesame ( Sesame indicum L.) in a Sudan savanna zone of Nigeria. Ph.D thesis. Department of Crop Production, University of Maiduguri, Maiduguri. 145pp.

Imoloame E.O., Joshua, S.D. and Gworgwor, N.A. (2010). Economic assessment of some pre-Emergence herbicides in the Sudan savanna zone of Nigeria. J. Agric, Biotechnol. Sustain. Devel. 2(2): 21-26.

Jannink J.K., Orf J.H., Jordan N.R., Shaw R.G. (2000). Index selection for weed suppressive ability in soyabean. Crop Science. 40(4): 1087 - 1094.

Joshi N.C. (2001), Weed Control Manual $5^{\text {th }}$ Edition. Delhi Research Station, Delhi. 538pp.

Joshua S.D. and Gworgwor, N.A. (2000). Effect of weeding regime on crop performance in millet-cowpea Intercrop in the semi-arid zone of Nigeria. Nigerian Journal of Weed Science 13: $63-68$.

Kureh I., Alabi S.O and Kamara A.Y. (2005). Response of Soybean Genotypes to Alectravogelii Infestation under Natural Field Condition. Tropicaltuira. 23:183-189.

Mickelson J.A. and Renner K.A. (1997).Weed control using reduced rates of pre-emergence herbicides in narrow and wide row spaced. Journal of Production Agriculture 10: 431-437

Murphy T.R. and Gossett B.J. ( 1981). Influence of shading by soybean ( Glycine max) and weed suppression. Weed Science 29:610-615.

Ogbungbile A. O. Ndahi W., Lagoke S. T. O. (1982). Economic Evaluation Of herbicide use in maize production. Paper presented In: Proceedings of The 11th Annual Conference of Weed Science Society of Nigeria. Eds. B. A. Adenuga, I. O. Akobundu and A. Ayeni. Ahmadu Bello University, Zaria, Nigeria, March, 1982, 45pp.

Ogungbile A.O. and Lagoke S.T.O. (1986). On-farm evaluation of the economics of chemical weed control in oxen- mechanized maize production in Nigerian savanna. Trop. Pest Management. 32:273-276. 
Okereke U.O., (1983). Weed control in transplanted dry and rainy season tomatoes (Lycopersiconesculentum Mill) crops with gramoxone (Paraquat) and Sencor. The $5^{\text {th }}$ Annual Conference of Horticultural Society of Nigeria Nov. 6-9, 1985. University of Nigeria Nsukka, Nigeria. Pp 6-9.

Onwueme I.C. and Sinha T.D. (1991). Field Crops Production in Tropical Africa. Principles and Practice C.T.A. Wagenigen. The Netherlands. 348pp.

Peer F.A., Badrul lone B.A., Qayoom S., Ahmed L. Khanday B.A., Ssingh P., and Singh G. (2013). Effect of weed Control Methods on Yield and Yield Attributes of Soyabean. African Journal of Agricultural Research 8(48): 6135 - 6141.

Remison S.U. (1979). Effect of weeding and nitrogen treatments on yield of maize in Nigeria. Weed Research. 19:71-74.

Shrock W.A. and Monaco T.J. (1980). Resent development in weed management programme for tomatoes. Proceedings of $33^{\text {rd }}$ Annual Meeting of the Southern Weed Science Society, Southern Weed Science. 33:90-92.

Sinha T.D. and Lagoke S.T.O. (1984). Weed control in irrigated tomatoes (Lycopersiconesculentum Mill) Trop. Pest Management. 30: $18-25$.

Sodangi I.A., Gworgwor N.A., and Joshua S.D.. (2006). Effects of weed interference and inter-row spacing on productivity of soyabean (Glycine Max (L) Merril) in Maiduguri, Nigeria. Nigerian Journal of Weed Science. 19: $33-40$.

Sodangi I.A., Gworgwor N.A., and Joshua S.D. (2007).Effects of weed interference on narrow row soybean in a semi-arid environment. Production Agriculture and Technology 3(2): 117-123

Sodangi I.A., Gworgwor N.A. and Joshua S.D. (2011). Effects of Inter-row, spacing and NPk fertilizer in weed suppression by soybean (Glycine Max) in Sudan Savanna of Nigeria.

Thakare K.G. Chore C.N, Deolate R.D., Kamble P.S. Suyata B.P., Shradha R.L. (2006). Influence of nutrient and hornimes on biochemical, yield and yield contributing parameters of soybean, J. Soils and Crops 16(1): 210-216.

Veeramani A., Palchamy A, Ramasamy S, Rangaraju G.(2001). Integrated Weed Management in Soybean ( Glycine max ( L.) Merril)under various plant densities. Madras Agric. J. 88 (7-9): 451-456

Yelverton F.H. and Coble H.D. (1991). Narrow row spacing and canopy formation reduces Weed resurgence in soybeans ( Glycine max). Weed Technology 5: 169-174. 
TABLE 1: The Influence of different methods of weed control on weed dry matter, 2012 and 2013.

\begin{tabular}{|c|c|c|c|c|c|c|c|}
\hline \multirow{3}{*}{ Treatment } & \multirow{3}{*}{ Rate kg a.i./ha } & \multicolumn{6}{|c|}{ WEED DRY MATTER } \\
\hline & & \multicolumn{2}{|c|}{ 6WAS } & \multicolumn{3}{|c|}{ HARVEST } & \multirow[b]{2}{*}{ Mean } \\
\hline & & 2012 & 2013 & Mean & $\underline{2012}$ & 2013 & \\
\hline Metolachlor & 1.5 & $246.7 b c$ & $144.0 \mathrm{~cd}$ & $195.3 b c$ & $1777.8 \mathrm{ab}$ & 1022.0ab & $\overline{1399.9} \mathrm{ab}$ \\
\hline Metolachlor & 2.0 & 428.0ab* & $146.3 \mathrm{~cd}$ & $287.1 b$ & $955.6 a b$ & 999.9ab & 977.7ab \\
\hline Metolachlor & 2.5 & 460.9ab & $168.9 b c$ & $314.9 b$ & 1911.1a & $666.6 \mathrm{bc}$ & $1288.8 \mathrm{ab}$ \\
\hline Pendimethalin & 1.5 & 435.6ab & $128.5 \mathrm{~cd}$ & $282.0 \mathrm{~b}$ & 1627.0ab & $633.2 \mathrm{bc}$ & 1130.1ab \\
\hline Pendimethalin & 2.0 & $164.0 \mathrm{bc}$ & 197.1ab & $180.6 b c$ & $1555.6 \mathrm{ab}$ & $822.2 \mathrm{ab}$ & 1188.9ab \\
\hline Pendimethalin & 2.5 & $216.9 \mathrm{bc}$ & 187.3ab & $202.1 b c$ & 1288.9ab & $1144.4 a b$ & 1216.7ab \\
\hline Metolachlor + diuron & $1.5+0.5$ & $206.2 b c$ & $117.7 \mathrm{~cd}$ & $162.0 \mathrm{bc}$ & 1422.6ab & 833.3ab & 1128.9ab \\
\hline Metolachlor + diuron & $2.0+1.0$ & $276.0 \mathrm{bc}$ & $136.0 \mathrm{~cd}$ & $206.0 \mathrm{bc}$ & $1511.5 \mathrm{ab}$ & $684.4 b c$ & 1098.0ab \\
\hline Metolachlor + diuron & $2.5+1.5$ & $192.0 \mathrm{bc}$ & $128.9 \mathrm{~cd}$ & $160.4 b c$ & 1018.1ab & $955.6 a b$ & $986.8 \mathrm{ab}$ \\
\hline Pendimethalin+diuron & $1.5+0.5$ & 393.3ab & $155.7 \mathrm{bc}$ & $274.5 b$ & 1533.3ab & $777.8 \mathrm{bc}$ & $1155.5 a b$ \\
\hline Pendimethalin+diuron & $2.0+1.0$ & 353.3ab & $268.9 a b$ & $311.1 b$ & 1044.5ab & $788.9 b c$ & $916.7 a b$ \\
\hline Pendimethalin+diuron & $2.5+1.5$ & $175.1 \mathrm{bc}$ & $162.7 \mathrm{bc}$ & $168.9 b c$ & $333.7 a b$ & 733.3bc & $533.5 a b$ \\
\hline Metolachlor +। SHW@6WAS & 2.0 & $212.9 b c$ & $129.1 \mathrm{~cd}$ & $171.0 \mathrm{bc}$ & $62.6 \mathrm{~cd}$ & 300.0de & 181.3de \\
\hline Pendimethalin+ I SHW@6WAS & 2.0 & $445.8 a b$ & $117.5 \mathrm{~cd}$ & $281.7 b$ & $14.0 \mathrm{~d}$ & 188.9ef & 101.4ef \\
\hline Metolachlor +diuron+I SHW@6WAS & $1.5+0.5$ & $252.9 \mathrm{bc}$ & $157.8 \mathrm{bc}$ & $205.3 b c$ & $1.0 \mathrm{~d}$ & $155.5 f$ & $78.3 f$ \\
\hline Pendimethalin+diuron+ISHW@6WAS & $1.5+0.5$ & $176.0 \mathrm{bc}$ & $164.4 \mathrm{bc}$ & $170.2 b c$ & $222.9 \mathrm{bc}$ & $377.7 \mathrm{~cd}$ & $300.3 b c$ \\
\hline Hoe weeding at $3 \& 6$ WAS & - & $57.3 c$ & $54.9 d$ & $56.1 \mathrm{c}$ & 333.7ab & $155.9 f$ & $244.8 \mathrm{~cd}$ \\
\hline Weedy Check & - & $622.2 a$ & 291.3a & $456.8 \mathrm{a}$ & $1377.8 \mathrm{ab}$ & $1422.2 \mathrm{a}$ & $1400.0 \mathrm{a}$ \\
\hline $\operatorname{SE}( \pm)$ & & 26.63 & 9.9 & 2.01 & 150.50 & 59.61 & 12.3 \\
\hline
\end{tabular}

WAS=weeks after sowing * =columns with the same letters are not significantly different at $5 \%$ level of probability according to Duncan's Multiple Range Test (DMRT) SHW= Supplementary hoe weeding 
Imoloame, 2014

TABLE 2: The Influence of different methods of weed control methods on weed cover scores, 2012 and 2013.

\begin{tabular}{|c|c|c|c|c|c|c|c|}
\hline \multirow{3}{*}{ Treatment } & \multirow[b]{2}{*}{ Rate $\mathrm{kg}$ a.i.Iha } & \multicolumn{6}{|c|}{ WEED COVER SCORES } \\
\hline & & \multicolumn{2}{|c|}{ 6WAS } & \multicolumn{4}{|c|}{ HARVEST } \\
\hline & & 2012 & 2013 & Mean & 2012 & 2013 & Mean \\
\hline Metolachlor & 1.5 & $4.0 b c$ & $70 b^{*}$ & $55 b$ & $6.7 a b$ & $9.7 a$ & $8.2 a b$ \\
\hline Metolachlor & 2.0 & $3.7 b c$ & $4.5 b c$ & $4.1 b c$ & $6.0 \mathrm{ab}$ & $9.0 a$ & $7.5 b c$ \\
\hline Metolachlor & 2.5 & $4.3 b c$ & $3.2 e$ & $3.8 b c$ & $4.2 \mathrm{~cd}$ & $8.7 a$ & $6.4 b c$ \\
\hline Pendimethalin & 1.5 & $3.3 b c$ & 3.7de & $3.5 \mathrm{~cd}$ & $6.7 a b$ & $8.8 a$ & $7.6 \mathrm{bc}$ \\
\hline Pendimethalin & 2.0 & $1.8 \mathrm{~cd}$ & $6.2 \mathrm{bc}$ & $4.0 \mathrm{bc}$ & $5.3 b c$ & $8.3 a$ & $6.8 \mathrm{bc}$ \\
\hline Pendimethalin & 2.5 & $4.0 \mathrm{bc}$ & $6.7 \mathrm{bc}$ & $5.3 b c$ & $6.7 a b$ & $8.0 \mathrm{a}$ & $7.3 b c$ \\
\hline Metolachlor + diuron & $1.5+0.5$ & $1.8 \mathrm{~cd}$ & $3.5 \mathrm{de}$ & $2.7 e$ & $3.2 \mathrm{de}$ & 7.7ab & $5.4 \mathrm{e}$ \\
\hline Metolachlor + diuron & $2.0+1.0$ & $2.3 \mathrm{bc}$ & $4.8 \mathrm{bc}$ & $3.6 \mathrm{~cd}$ & $6.3 a b$ & $8.0 \mathrm{a}$ & $7.2 b c$ \\
\hline Metolachlor +diuron & $2.5+1.5$ & $1.8 \mathrm{~cd}$ & $2.8 \mathrm{e}$ & $2.3 e$ & $3.5 \mathrm{de}$ & $7.7 a$ & 5.6de \\
\hline Pendimethalin+ diuron & $1.5+0.5$ & $4.0 \mathrm{bc}$ & $5.3 b c$ & $4.7 \mathrm{bc}$ & $8.7 a b$ & $8.7 a$ & 8.7ab \\
\hline Pendimethalin+ diuron & $2.0+1.0$ & $2.8 b c$ & $4.7 \mathrm{bc}$ & $3.8 b c$ & $7.8 \mathrm{ab}$ & $8.0 a$ & $7.9 a b$ \\
\hline Pendimethalin+ diuron & $2.5+1.5$ & $1.7 \mathrm{~cd}$ & $5.0 \mathrm{bc}$ & 3.3de & $3.7 \mathrm{~cd}$ & $8.0 \mathrm{a}$ & $5.8 \mathrm{~cd}$ \\
\hline Metolachlor +I SHW@6WAS & 2.0 & $1.3 d$ & $3.8 \mathrm{~cd}$ & $2.6 \mathrm{e}$ & $1.8 \mathrm{ef}$ & $3.7 \mathrm{c}$ & $2.8 f$ \\
\hline Pendimethalin+ I SHW@6WAS & 2.0 & $2.8 b c$ & $2.8 \mathrm{e}$ & 2.8de & $1.5 f$ & $4.7 \mathrm{~b}$ & $3.1 f$ \\
\hline Metolachlor+diuron+1SHW@6WAS & $1.5+0.5$ & $5.0 b$ & $3.1 \mathrm{e}$ & $4.1 \mathrm{bc}$ & $3.8 \mathrm{~cd}$ & $2.3 c$ & $3.1 f$ \\
\hline Pendimethalin+diuron+ISHW@6WAS & $1.5+0.5$ & $2.0 \mathrm{~cd}$ & $4.5 b c$ & 3.3de & $1.7 f$ & $3.0 \mathrm{c}$ & $2.3 f$ \\
\hline Weeding at $3 \& 6$ WAS & - & $1.8 \mathrm{~cd}$ & $5.0 \mathrm{bc}$ & $3.4 \mathrm{de}$ & $1.3 f$ & $3.5 c$ & $2.4 f$ \\
\hline Weedy Check & - & $9.0 a$ & $9.8 a$ & $9.4 a$ & $10.0 \mathrm{a}$ & $1.0 \mathrm{a}$ & $10.0 \mathrm{a}$ \\
\hline $\mathrm{SE}( \pm)$ & & 0.30 & 0.49 & 0.03 & 0.43 & 0.39 & 0.05 \\
\hline
\end{tabular}

WAS=Weeks after sowing ${ }^{*}=$ columns with the same letters are not significantly different at $5 \%$ level of probability according to Duncan's Multiple Range Test (DMRT) SHW= Supplementary hoe weeding 
Imoloame, 2014

TABLE 3: The Influence of different methods of weed control Onphytotoxity of soybean

\begin{tabular}{|c|c|c|c|c|c|c|c|c|c|c|}
\hline \multirow[b]{2}{*}{ Treatment } & \multirow[b]{2}{*}{ Rate kg a.i./ha } & \multicolumn{9}{|c|}{ PHYTOTOXICITY RATING } \\
\hline & & \multicolumn{2}{|c|}{ 2WAS } & & \multicolumn{2}{|c|}{ 4WAS } & & \multicolumn{3}{|l|}{ 8WAS } \\
\hline & & 2012 & 2013 & Mean & 2012 & 2013 & Mean & 2012 & 2013 & Mean \\
\hline Metolachlor & 1.5 & 1.0 & $1.0 b$ & $1.0 \mathrm{~b}$ & 1.0 & 1.0 & 1.0 & 1.0 & 1.0 & 1.0 \\
\hline Metolachlor & 2.0 & 1.0 & $1.0 \mathrm{~b}$ & $1.0 b$ & 1.0 & 1.0 & 1.0 & 1.0 & 1.0 & 1.0 \\
\hline Metolachlor & 2.5 & 1.7 & $1.0 \mathrm{~b}$ & $1.3 a b$ & 1.0 & 1.0 & 1.0 & 1.0 & 1.0 & 1.0 \\
\hline Pendimethalin & 1.5 & 3.7 & $1.6 b^{*}$ & $2.6 a b$ & 1.0 & 1.0 & 1.0 & 1.0 & 1.0 & 1.0 \\
\hline Pendimethalin & 2.0 & 1.0 & $2.7 \mathrm{a}$ & $1.8 \mathrm{ab}$ & 1.0 & 1.0 & 1.0 & 1.0 & 1.0 & 1.0 \\
\hline Pendimethalin & 2.5 & 3.7 & $2.3 b$ & $3.0 \mathrm{a}$ & 1.0 & 1.0 & 1.0 & 1.0 & 1.0 & 1.0 \\
\hline Metolachlor +diuron & $1.5+0.5$ & 2.0 & $1.0 \mathrm{~b}$ & $1.5 a b$ & 1.0 & 1.0 & 1.0 & 1.0 & 1.0 & 1.0 \\
\hline Metolachlor +diuron & $2.0+1.0$ & 3.0 & $1.0 \mathrm{~b}$ & $2.0 \mathrm{ab}$ & 1.0 & 1.0 & 1.0 & 1.0 & 1.0 & 1.0 \\
\hline Metolachlor +diuron & $2.5+1.5$ & 1.6 & $1.3 b$ & $1.5 a b$ & 1.0 & 1.0 & 1.0 & 1.0 & 1.0 & 1.0 \\
\hline Pendimethalin+ diuron & $1.5+0.5$ & 3.3 & $1.3 b$ & 2.3ab & 1.0 & 1.0 & 1.0 & 1.0 & 1.0 & 1.0 \\
\hline Pendimethalin+ diuron & $2.0+1.0$ & 2.3 & $1.7 b$ & $2.0 \mathrm{ab}$ & 1.0 & 1.0 & 1.0 & 1.0 & 1.0 & 1.0 \\
\hline Pendimethalin+ diuron & $2.5+1.5$ & 2.0 & $3.3 a$ & $2.7 a b$ & 1.0 & 1.0 & 1.0 & 1.0 & 1.0 & 1.0 \\
\hline Metolachlor + I SHW@6WAS & 2.0 & 2.0 & $3.3 a$ & $2.7 a b$ & 1.0 & 1.0 & 1.0 & 1.0 & 1.0 & 1.0 \\
\hline Pendimethalin+ I SHW@6WAS & 2.0 & 1.3 & $1.3 b$ & $1.3 a b$ & 1.0 & 1.0 & 1.0 & 1.0 & 1.0 & 1.0 \\
\hline Metolachlor + diuron+I SHW & $1.5+0.5$ & 1.7 & $1.0 \mathrm{~b}$ & 1.3ab & 1.0 & 1.0 & 1.0 & 1.0 & 1.0 & 1.0 \\
\hline Pendimethalin+diuron+ISHW & $1.5+0.5$ & 3.3 & $1.3 b$ & $2.3 a b$ & 1.0 & 1.0 & 1.0 & 1.0 & 1.0 & 1.0 \\
\hline Weeding at $3 \& 6$ WAS & - & 1.7 & $1.0 \mathrm{~b}$ & $1.3 a b$ & 1.0 & 1.0 & 1.0 & 1.0 & 1.0 & 1.0 \\
\hline Weedy Check & - & 1.7 & $1.0 \mathrm{~b}$ & $1.3 a b$ & 1.0 & 1.0 & 1.0 & 1.0 & 1.0 & 1.0 \\
\hline $\operatorname{SE}( \pm)$ & & 0.24 & 0.12 & 0.02 & 0.11 & 0.0 & 0.00 & 0.0 & 0.0 & 0.00 \\
\hline
\end{tabular}

WAS=Weeks after sowing ${ }^{*}=$ columns with the same letters are not significantly different at $5 \%$ level of probability according to Duncan's Multiple Range Test (DMRT) SHW= Supplementary hoe weeding 
Imoloame, 2014

TABLE 4: The Influence of different methods of weed control on plant height of soybean, 2012 and 2013.

\begin{tabular}{|c|c|c|c|c|c|c|c|}
\hline \multirow[b]{2}{*}{ Treatment } & \multirow[b]{2}{*}{ Rate kg a.i.lha } & \multicolumn{6}{|c|}{ PLANT HEIGHT (cm²) } \\
\hline & & \multicolumn{2}{|c|}{ 6WAS } & \multicolumn{4}{|c|}{ HARVEST } \\
\hline & & 2012 & 2013 & Mean & 2012 & 2013 & Mean \\
\hline Metolachlor & 1.5 & $26.5 a$ & $23.8 \mathrm{ab}$ & $25.2 a b$ & $53.1 \mathrm{a}$ & $37.7 a b$ & $45.4 a b$ \\
\hline Metolachlor & 2.0 & $28.7 a$ & $25.2 a b$ & $26.9 a b$ & $49.9 a$ & $39.6 a b$ & $44.8 a b$ \\
\hline Metolachlor & 2.5 & $25.9 a$ & $23.8 \mathrm{ab}$ & $24.9 a b$ & $50.0 a$ & $40.1 a b$ & 45.1ab \\
\hline Pendimethalin & 1.5 & $25.6 a$ & $25.3 a b$ & $25.4 a b$ & $43.8 a$ & $43.9 a b$ & $43.9 \mathrm{ab}$ \\
\hline Pendimethalin & 2.0 & $28.2 a$ & $20.7 b c$ & $24.5 a b$ & $51.5 a$ & $28.1 \mathrm{~cd}$ & $39.8 \mathrm{~cd}$ \\
\hline Pendimethalin & 2.5 & $20.9 a$ & $24.3 a b$ & $22.6 b c$ & $45.3 a$ & $39.1 \mathrm{ab}$ & $42.2 a b$ \\
\hline Metolachlor + diuron & $1.5+0.5$ & $27.1 \mathrm{a}$ & $25.7 a b$ & $26.4 a b$ & $48.6 a$ & $43.4 a b$ & $46.0 \mathrm{ab}$ \\
\hline Metolachlor + diuron & $2.0+1.0$ & $23.5 a$ & $26.8 \mathrm{a}$ & $25.1 a b$ & $47.7 a$ & $48.5 a b$ & 48.1ab \\
\hline Metolachlor + diuron & $2.5+1.5$ & $28.5 a$ & $25.0 \mathrm{ab}$ & $26.7 a b$ & $57.0 \mathrm{a}$ & $40.1 a b$ & $48.6 a$ \\
\hline Pendimethalin+ diuron & $1.5+0.5$ & $25.5 a$ & $26.3 a b$ & $25.9 a b$ & $50.2 a$ & $40.6 a b$ & $45.4 a b$ \\
\hline Pendimethalin+ diuron & $2.0+1.0$ & $23.7 a$ & 23.3ab & $23.5 b c$ & $45.0 \mathrm{a}$ & $39.3 a b$ & 42.1ab \\
\hline Pendimethalin+ diuron & $2.5+1.5$ & $27.2 \mathrm{a}$ & 23.3ab & $25.2 a b$ & $51.7 a$ & $32.7 \mathrm{bc}$ & $42.2 \mathrm{ab}$ \\
\hline Metolachlor +| SHW@6WAS & 2.0 & $23.4 a$ & 23.7ab & $23.5 a b$ & $42.4 a$ & $38.1 a b$ & $40.3 b c$ \\
\hline Pendimethalin+ I SHW@6WAS & 2.0 & $23.8 \mathrm{a}$ & $24.7 a b$ & 24.3ab & $42.5 a$ & $37.8 a b$ & $40.1 \mathrm{bc}$ \\
\hline Metolachlor + diuron+l SHW@6WAS & $1.5+0.5$ & $29.6 a$ & $28.5 a$ & $29.1 \mathrm{a}$ & $49.5 a$ & $50.7 a$ & $50.1 \mathrm{a}$ \\
\hline Pendimethalin+diuron+ISHW@6WAS & $1.5+0.5$ & $21.8 \mathrm{a}$ & $23.5 \mathrm{ab}$ & $22.7 \mathrm{bc}$ & 44.2ab & 43.1ab & 43.7ab \\
\hline Weedy Check & - & $20.1 a$ & $18.1 \mathrm{c}$ & $21.0 \mathrm{c}$ & $41.9 \mathrm{a}$ & $24.5 d$ & $36.7 d$ \\
\hline $\operatorname{SE}( \pm)$ & & 0.71 & 0.31 & 0.05 & 1.03 & 1.15 & 0.09 \\
\hline
\end{tabular}


Imoloame, 2014

TABLE 5: The Influence of different weed control methods on soybean crop vigour, 2012 and 2013.

\begin{tabular}{|c|c|c|c|c|c|c|c|}
\hline \multirow[b]{2}{*}{ Treatment } & \multirow[b]{2}{*}{ Rate kg a.i./ha } & \multicolumn{6}{|c|}{ CROP VIGOUR } \\
\hline & & \multicolumn{3}{|c|}{6 WAS } & \multicolumn{2}{|c|}{9 WAS } & \multirow[b]{2}{*}{ Mean } \\
\hline & & 2012 & 2013 & Mean & 2012 & 2013 & \\
\hline Metolachlor & 1.5 & $82 a$ & $80 a b^{*}$ & $81 a$ & $8.2 a$ & $7.5 \mathrm{bc}$ & $7.8 \mathrm{ab}$ \\
\hline Metolachlor & 2.0 & $7.5 a$ & $8.2 a b$ & $7.8 a b$ & $8.2 a$ & $7.8 a b$ & $8.0 a b$ \\
\hline Metolachlor & 2.5 & $7.5 a$ & $8.0 \mathrm{ab}$ & $7.8 a b$ & $8.5 a$ & $7.2 \mathrm{bc}$ & $7.8 \mathrm{ab}$ \\
\hline Pendimethalin & 1.5 & $7.2 \mathrm{a}$ & 7.7ab & $7.4 a b$ & $7.0 \mathrm{a}$ & $7.0 \mathrm{bc}$ & $7.0 \mathrm{~d}$ \\
\hline Pendimethalin & 2.0 & $8.2 a$ & $7.0 \mathrm{bc}$ & $7.6 a b$ & $9.2 \mathrm{a}$ & $7.0 \mathrm{bc}$ & $8.1 a b$ \\
\hline Pendimethalin & 2.5 & $7.5 a$ & $7.2 a b$ & 7.3ab & $7.3 \mathrm{a}$ & $6.8 \mathrm{c}$ & $7.1 \mathrm{~cd}$ \\
\hline Metolachlor + diuron & $1.5+0.5$ & $7.7 a$ & $8.3 a b$ & $8.0 \mathrm{a}$ & $8.5 a$ & $8.0 \mathrm{ab}$ & $8.3 a b$ \\
\hline Metolachlor + diuron & $2.0+1.0$ & $7.2 a$ & $8.5 \mathrm{ab}$ & 7.8ab & $7.7 a$ & $8.2 a b$ & $7.9 \mathrm{ab}$ \\
\hline Metolachlor + diuron & $2.5+1.5$ & $8.2 a$ & $8.0 a b$ & $8.1 \mathrm{a}$ & $8.7 a$ & $7.3 b c$ & $8.0 a b$ \\
\hline Pendimethalin+ diuron & $1.5+0.5$ & $7.8 \mathrm{a}$ & $8.2 a b$ & $8.0 \mathrm{a}$ & $8.5 a$ & $7.8 \mathrm{ab}$ & $8.2 a b$ \\
\hline Pendimethalin+ diuron & $2.0+1.0$ & $7.3 a$ & $7.8 a b$ & 7.6ab & $7.8 \mathrm{a}$ & 8.0ab & 7.9ab \\
\hline Pendimethalin+ diuron & $2.5+1.5$ & $7.7 \mathrm{a}$ & $6.3 \mathrm{~cd}$ & $7.0 \mathrm{bc}$ & $8.3 a$ & $6.8 \mathrm{c}$ & $7.6 \mathrm{bc}$ \\
\hline Metolachlor +I SHW@6WAS & 2.0 & $7.5 a$ & $7.5 a b$ & $7.5 \mathrm{ab}$ & $7.8 \mathrm{a}$ & 7.7ab & $7.8 \mathrm{bc}$ \\
\hline Pendimethalin+ I SHW@6WAS & 2.0 & $7.3 a$ & $7.5 a b$ & $7.4 a b$ & $7.8 \mathrm{a}$ & $7.3 b c$ & $7.6 \mathrm{bc}$ \\
\hline Metolachlor + diuron+I SHW@6WAS & $1.5+0.5$ & $7.3 a$ & $8.8 a$ & $8.1 \mathrm{a}$ & 8.3a & $9.2 a$ & $8.8 a$ \\
\hline Pendimethalin+ diuron+I SHW & $1.5+0.5$ & $7.2 \mathrm{a}$ & $7.8 \mathrm{ab}$ & $7.5 a b$ & $7.7 a$ & $7.5 b c$ & $7.6 \mathrm{bc}$ \\
\hline Weeding at $3 \& 6$ WAS & - & $7.5 a$ & $8.7 a b$ & $8.1 \mathrm{a}$ & $7.5 a$ & $8.5 a b$ & $8.0 \mathrm{ab}$ \\
\hline Weedy Check & - & $7.8 \mathrm{a}$ & $5.2 d$ & $6.5 \mathrm{c}$ & $7.0 \mathrm{a}$ & $4.3 d$ & $5.7 e$ \\
\hline $\operatorname{SE}( \pm)$ & & 0.10 & 0.16 & 0.01 & 0.15 & 0.16 & $0-01$ \\
\hline
\end{tabular}

I=Weeks after sowing $2=$ columns with the same letters are not significantly different at $5 \%$ level of probability according to Duncan's Multiple Range Test (DMRT) $3=$ Supplementary hoe weeding 
Imoloame, 2014

TABLE 6: The Influence of different methods of weed control on 100-seed weight and grain yield (kg/ha), 2012 and 2013.

\begin{tabular}{|c|c|c|c|c|c|c|c|}
\hline \multirow[t]{2}{*}{ TreatmentRate kg a.i./ha } & & \multicolumn{6}{|c|}{ 100-seed weight $(\mathrm{g})$ Grain Yield ( $\mathrm{kg} / \mathrm{ha}$ ) } \\
\hline & & 2012 & 2013 & Mean & 2012 & 2013 & Mean \\
\hline Metolachlor & 1.5 & $13.3 \mathrm{a}$ & $13.9 \mathrm{de}$ & $13.6 b$ & $1764.7 a b$ & $2398 \mathrm{~cd}$ & $1002.3 b c$ \\
\hline Metolachlor & 2.0 & $13.1 \mathrm{a}$ & $14.4 \mathrm{bc}$ & $13.8 \mathrm{ab}$ & $1759.7 \mathrm{ab}$ & $255.5 \mathrm{~cd}$ & $1007.6 \mathrm{bc}$ \\
\hline Metolachlor & 2.5 & 13.6a & $15.1 \mathrm{ab}$ & $14.3 a b$ & 2427.2ab & $283.2 \mathrm{~cd}$ & 1355.2ab \\
\hline Pendimethalin & 1.5 & $13.4 \mathrm{a}$ & $15.3 a b$ & $14.3 a b$ & $1345.8 b c$ & $378.9 \mathrm{~cd}$ & $862.3 \mathrm{~cd}$ \\
\hline Pendimethalin & 2.0 & $13.4 \mathrm{a}$ & $13.7 \mathrm{e}$ & $13.6 \mathrm{~b}$ & $2658.7 a$ & $208.1 \mathrm{~cd}$ & $1433.4 \mathrm{ab}$ \\
\hline Pendimethalin & 2.5 & $12.9 \mathrm{a}$ & $14.0 \mathrm{de}$ & $13.5 b$ & 1967.6ab & $276.6 \mathrm{~cd}$ & 1122.1ab \\
\hline Metolachlor + diuron & $1.5+0.5$ & $13.1 \mathrm{a}$ & $14.3 \mathrm{bc}$ & $13.7 \mathrm{~b}$ & 1893.3ab & $285.5 \mathrm{~cd}$ & $1089.7 \mathrm{bc}$ \\
\hline Metolachlor + diuron & $2.0+1.0$ & $13.0 \mathrm{a}$ & $14.4 \mathrm{bc}$ & $13.7 \mathrm{~b}$ & 1961.3ab & $481.6 \mathrm{bc}$ & $1221.5 a b$ \\
\hline Metolachlor + diuron & $2.5+1.5$ & $13.6 \mathrm{a}$ & $14.2 \mathrm{bc}$ & $13.9 \mathrm{ab}$ & $1946.8 \mathrm{ab}$ & $331.8 \mathrm{~cd}$ & 1139.3ab \\
\hline Pendimethalin+ diuron & $1.5+0.5$ & $13.6 \mathrm{a}$ & $14.7 \mathrm{ab}$ & $14.1 \mathrm{ab}$ & 2384.0ab & $393.1 \mathrm{~cd}$ & $1388.5 \mathrm{ab}$ \\
\hline Pendimethalin+ diuron & $2.0+1.0$ & $13.6 \mathrm{a}$ & $14.7 a b$ & $14.1 \mathrm{ab}$ & $1835.4 \mathrm{ab}$ & $556.6 \mathrm{bc}$ & $1196.0 \mathrm{ab}$ \\
\hline Pendimethalin+ diuron & $2.5+1.5$ & $13.6 \mathrm{a}$ & $14.2 \mathrm{~cd}$ & $13.9 \mathrm{ab}$ & $2340.9 \mathrm{ab}$ & $268.5 \mathrm{~cd}$ & $1304.7 a b$ \\
\hline Metolachlor +I SHW@6WAS & 2.0 & $13.4 \mathrm{a}$ & $14.5 \mathrm{bc}$ & $14.1 \mathrm{ab}$ & $2585.6 a$ & $606.6 b c$ & 1596.1ab \\
\hline Pendimethalin+ I SHW@6WAS & 2.0 & $13.5 \mathrm{a}$ & $14.7 \mathrm{ab}$ & $14.1 \mathrm{ab}$ & $2320.2 a b$ & $447.7 \mathrm{bc}$ & $1384.0 \mathrm{ab}$ \\
\hline Metolachlor +diuron+I SHW & $1.5+0.5$ & $13.7 \mathrm{a}$ & $15.8 \mathrm{a}$ & $14.7 a$ & $2397.8 \mathrm{ab}$ & 1013.1a & $1705.4 a$ \\
\hline Pendimethalin+ diuron+I SHW & $1.5+0.5$ & $13.1 \mathrm{a}$ & $15.5 \mathrm{ab}$ & $14.2 a b$ & $2320.0 \mathrm{ab}$ & $560.5 b c$ & $1440.2 \mathrm{ab}$ \\
\hline Weeding at $3 \& 6$ WAS & - & $13.3 \mathrm{a}$ & $15.3 \mathrm{ab}$ & $14.2 \mathrm{ab}$ & $2345.5 a b$ & 803.7ab & 1574.6ab \\
\hline Weedy Check & - & $13.3 a$ & 13.9de & $13.5 b$ & $623.6 \mathrm{c}$ & $108.2 d$ & $365.9 d$ \\
\hline $\mathrm{SE}( \pm)$ & & 0.10 & 0.11 & 0.01 & 86.48 & 37.71 & 6.69 \\
\hline
\end{tabular}

WAS=Weeks after sowing ${ }^{*}=$ columns with the same letters are not significantly different at $5 \%$ level of probability according to Duncan's Multiple Range Test (DMRT) SHW= Supplementary hoe weeding. 